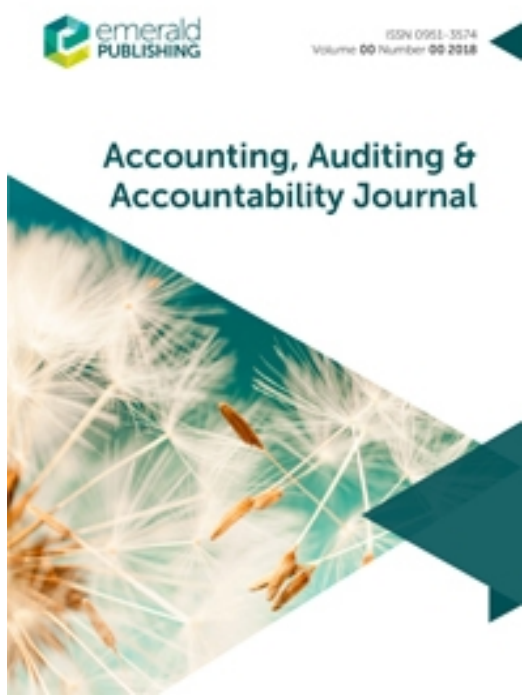

\title{
Dissensus and democratic accountability in a case of conflict.
}

\begin{tabular}{|r|l|}
\hline Journal: & Accounting, Auditing \& Accountability Journal \\
\hline Manuscript ID & AAAJ-11-2016-2780.R2 \\
\hline Manuscript Type: & Research Paper \\
\hline Keywords: & Accountability, Oil, Democracy, Indigenous \\
\hline \multicolumn{2}{|l}{} \\
\end{tabular}

SCHOLARONE $^{\text {m }}$
Manuscripts $^{\text {Manusion }}$ 
Dissensus and democratic accountability in a case of conflict.

Purpose - This paper explores diverse practices of the giving and demanding of democratic accountability within a case of conflict around deep-sea petroleum exploration in Aotearoa New Zealand. These practices include submissions and consultations, partnership between Indigenous Peoples and a settler-colonial government, and dissensus. These are theorised through the political thought of Jacques Rancière.

Methodology - A single case study approach is employed that seeks to particularise, and draws on interview, documentary and media materials.

Findings - By examining a case of conflict, we find that as opportunities for participation in democratic accountability processes are eroded, political dissensus emerges to demand parts in the accountability process. Dissensus creates counter forums within a wider understanding of democratic accountability. In this case, individuals and organisations move between police (where hierarchy counts those with a part) and politics (exercised when this hierarchy is disrupted by dissensus) to demand parts as police logics become more and less democratic. These parts are then utilised towards particular interests, but in this case, to also create additional parts for those with none.

Originality/value - This study privileges demands for accountability through dissensus as fundamental to democratic accountability, rather than just account giving and receiving. That is, who is or who is not included - who has a stake or a part - is crucial in a broader understanding of democratic accountability. This provides democratic accountability with a radical potential for creating change. The study also advances thinking on democratic accountability by drawing from Indigenous perspectives and experiences in a settler-colonial context. 


\section{Introduction}

Accountability can be a fundamentally radical concept (Owen, 2008). While accountability research within the accounting literature has generally focused on managerial perspectives within corporate accountability frameworks, an enduring literature around democratic accountability has sought to incorporate alternative perspectives around the role of accountability in democracy (Stewart, 1984; Day and Klein, 1987; Gray and Jenkins, 1993; Owen, 2008; Brown, 2009; Brown, Dillard and Hopper, 2015; Gallhofer, Haslam and Yonekura, 2015; Catchpowle and Smyth, 2016; Brown and Tregidga, 2017). This broadens out and opens up the potential for how democratic accountability is understood and exercised across diverse contexts (Brown and Dillard, 2015a). However, virtually all of this literature is conceptual/normative - this is how democratic accountability could or should function - but empirical realities are complex and nuanced. In response, there have been a number of calls for examining democratic accountability in empirical settings (Owen, 2008; Brown and Tregidga, 2017).

One pivotal contribution in recent times comes from Brown and Tregidga (2017) who argue for a more careful analysis of the role of dissensus in demands for democratic accountability. They draw from political theorist Jacques Rancière who distinguishes between police (a distribution of the sensible where hierarchy counts those with a part - i.e. typical State apparatus) and politics (exercised when this hierarchy is disrupted by dissensus and demands for a part by those with none - i.e. protests, social movements). Opening up accounting/accountability research to non-corporate actors can reveal where the less comfortable areas of conflict lie (Owen, 2008) because in order to hold the powerful to account for their actions, voice must be given to (O'Dwyer, Unerman and Bradley, 2005), or more appropriately taken by the less powerful (Rancière, 1999). Starting with this motivation, the present study seeks to explore how democratic accountability is understood and exercised within a conflicted setting that has dissensus at its heart, namely, deep-sea petroleum exploration in Aotearoa New Zealand.

At a time when prominent figures are talking about a climate crisis rather than climate change (Klein, 2014; Wretched of the Earth, 2019), deep sea petroleum exploration provides one issue with which to examine democratic accountability. The one-two punch of an economy built on fossil fuels is that when things go wrong, the results can be catastrophic - the interred carbon escapes at the source in the form of a spill or blowout like Deepwater Horizon in the Gulf of Mexico. If it goes right, then carbon is successfully combusted and released into the atmosphere and perpetuates the climate crisis (Klein, 2014). Deep sea petroleum exploration has become contested in many areas around the world (e.g., Babcock, 2012; Keil, 2015; Poulton, 2015; Windsor and McNicholas, 2012) and no less so in Aotearoa New Zealand. A central element in some of these contests is the manner in which citizens, organisations and governments interact, providing an opportunity for understanding notions of democratic accountability. In addition, a unique accountability relation concerns the partnership between the Indigenous Peoples of Aotearoa New Zealand, Māori, and the Government under Te Tiriti/Treaty of Waitangi [1]. Given New Zealand's settler colonial history (Walker, 1990; O'Regan, 1991; Anderson, Binney and Harris, 2016), relationships around Te Tiriti partnership are necessarily central to any analysis of accountability. These features make engagement around deep-sea petroleum exploration, a useful and novel site for examining democratic accountability relations.

This study contributes to prior work by positioning the forum for accounts, in addition to accounts themselves, as a radical characteristic of accountability. That is, both what constitutes a forum, and who is or who is not included in the forum - who has a stake or a part - is crucial in understanding democratic accountability. Rancière is deployed in this analysis for his distinction between politics and police and for where/when these occur in the democratic process. Our findings suggest that as official opportunities for participation in democratic accountability processes (e.g., consultation and submissions) are shut down, new political practices emerge to bridge a democratic deficit (e.g., dissensus). Dissensus thus creates alternative or counter forums in the process of demanding democratic accountability. Democratic accountability is a state of becoming where individuals and organisations move fluidly between politics and police to demand a part (a (self) recognised political identity and actor status). This part can then be used to achieve particular outcomes, and/or to create more parts for others with none. The partnership relationship between the Government of New Zealand and Māori provides a basis for questioning Rancière's rigid distinction between 
police and politics. When Indigenous Peoples are formally recognised in the police logics of the State through a history of political resistance and dissensus, then it becomes necessary to examine the aspects of police that are more or less democratic. In our case the partnership between State and Māori groupings holds the potential for alternative visions of democratic accountability and democracy itself.

The paper is structured as follows. Section two reviews and syntheses prior literature focusing on democratic accountability and then extends these with a close examination of the democratic thought of Jacques Rancière. After the research methods are set out in section three, we provide a brief contextualisation of the case, its actors and existing practices of democratic accountability in section four. Sections five and six present and discuss findings from the case through a Rancièrean lens. We provide concluding thoughts and opportunities for future research in the final section.

\section{Democratic accountability}

\section{Understanding accountability}

Accountability is said to reside in a "bottomless swamp" (Sinclair, 1995, p. 221). The more definitive the attempt to render the concept the more murky it becomes (Dahl, 1957 as cited in Sinclair, 1995). Accountability, however, is a process which contains both accounts and the giving and receiving of accounts, that is, a forum (Stewart, 1984; Greiling and Spraul, 2010). Dubnick and Justice (2004) suggest the concept can be "regarded as a kind of performative moral discourse, a form of governance that depends on the dynamic social interactions and mechanisms created within such a moral community" (Dubnick and Justice, 2004, p. 12). Greiling and Spraul (2010) articulate accountability as a process with information, debate and engagement, and potential sanctions and censure. Newell and Wheeler (2006) advocate placing rights at the heart of accountability struggles. They contend that the right to claim or demand accountability is fundamental to achieving other social, environmental and economic rights (See also Kaler (2002) on stakeholders as "claimants"). In this way accountability is not a product or outcome, nor an end in itself, but a means first of demanding a part or a say, and then of using that part towards specific goals.

In many cases the channel of accountability can be more important than the account itself (Gray, Owen and Maunders, 1991). Information forms the basis for judgment and action in the holding to account (Stewart, 1984). But information provision alone is insufficient (Greiling and Spraul, 2010). Without opportunities to hold to account (i.e. a forum for the account) (Bovens, 2007; Roberts, 2009) accountability cannot exist (see also Cooper and Owen, 2007). Ranson (2003) outlines a framework for democratic accountability which recognises the agonistic plurality and conflict in the forum for the account. He offers five core principles. These are: (1) membership and politics of presence; (2) participation, equality of voice and dissent; (3) deliberation and the space of reason; (4) judgement and collective rule and (5) accountability - as a "social and political process" (Day and Klein, 1987, p. 2). Shearer (2002) adds that accountability needs to be seen as "a moral phenomenon that both can and should be subject to ethical reflection" (p. 545; see also Broadbent, 1998; Roberts, 2009).

A suitable definition for our purposes is therefore that accountability is "an obligation to present an account of and answer for the execution of responsibilities to those who entrusted those responsibilities. On this obligation depends the allocation of praise and blame, reward and sanction" (Gray and Jenkins, 1993, p. 55, as cited in Smyth, 2012; 2017, see also Stewart, 1984; Roberts, 2009; Greiling and Spraul, 2010). Yet much accountability practice and research in the social accounting literature in particular has focused on analyses of the account - the information disclosed (or its inadequacy or absence) (e.g., Dierkes and Preston, 1977; Gray et al. 1991; Mathews, 1997; Parker, 2005; Owen, 2008; Deegan, 2016). Much neglected empirically is the process of accountability more broadly within this definition. Our study thus contributes by examining forums for accounts and, specifically, demands for accountability within and outside of conventional forums through Rancière's police-politics framework.

The dialogic accounting framework developed by Brown (2009), and informed by agonistic democracy, looks to take "ideological conflicts seriously" (p. 313). Agonistic democratic accountability takes the view that struggles between opposing hegemonic projects cannot be reconciled by "a fully inclusive rational consensus" 
(Mouffe, 2000, as cited in Brown and Dillard, 2015b, p. 10). Dillard and Brown (2012) argue that "commitment to a dialogic process leads to renewed commitment to the adversary as a moral/political being with a voice demanding the right to be heard and understood but not necessarily having the right to be accepted" (p. 6). Jacques Rancière has very recently been introduced into the accounting literature in response to the work of Brown and colleagues (Brown, 2009; 2017; Brown and Dillard, 2015a; 2015b). Li and Mckernan (2016) argue that by following the liberal agonistic approach of Mouffe (2000; 2005; 2013), Brown and colleagues are suggesting that political subjects must learn to play by the rules or be excluded; and that marginalized groups require external experts to be political subjects. A definitive articulation of what a political subject is and when politics, and hence democracy, occurs eclipses the potential for change as advocated, for example, by Rancière's politics (Li and McKernan, 2016).

Yet more recently, Brown and Tregidga (2017) have reinforced Li and McKernan's (2016) proposition that Rancière is useful for re-politicizing social and environmental accounting. In doing so, they emphasise the radical potential of counter accounts and suggest that rather than speaking for the oppressed, critical accountants can speak with them. Consequently, we see potential in a closer look at Rancière's concept of dissensus, and its relationship with longer term democratic processes. We suggest that the radical potential of accountability lies in the possibility of changing outcomes and more democratic forums that include political dissent enable this. Cooper and Johnston $(2012$, p. 625) put it succinctly, asking "what is the purpose of being given many broad-ranging accounts if you have no power to change things?" The ability to demand and attain rights - to change outcomes - is the radical potential of accountability. However, this requires having a part in the count in order to be heard as a speaking subject - to be included or include oneself in the process of accountability. This is why the democratic thought of Jacques Rancière needs careful consideration towards this potential.

\section{Jacques Rancière, democratic accountability and dissensus}

Rancière's thought enables us to explore how accountability is understood and exercised in this case study because of his emphasis on the role of dissensus in the democratic process (Rancière, 1992; 1999; 2006; 2010). Following Ruckstuhl (2017), Li and McKernan (2016) and Brown and Tregidga (2017) we suggest that particular struggles of accountability for Indigenous sovereignty, human rights, and against petroleum exploration are inextricably intertwined into a universal fight for equality. Rancière's concepts of 'police' and 'politics', dissensus rather than consensus; subjectivisation; and the relationship between the particular and the universal are each discussed in turn to define how the democratic accountability process is conceptualised in our study.

The way that the modern democratic State is structured is based on a logic of arkhe which presumes that a "determinate superiority is exercised over an equally determinate inferiority" (Rancière, 2010, p. 30) or those who are born to govern and those who are born to be governed. This is a natural state of inequality and it divides government from itself by dividing society from itself. It separates the exercise of government from the representation of society (Rancière, 2006, p. 49). Government, or the State, is always a tool of control utilised by the minority over the majority. The laws and institutions of the State are therefore tools to maintain the status quo and existing power structures within this. To have a democratic state with an elected parliament, be that election through birth, wealth, knowledge, or luck, striving towards equality is therefore a contradiction. To depart from this contradiction, Rancière (2010) distinguishes between police (which counts 'real' parts only) and politics (which counts those with no part).

Rancière (2010) identifies the dominant order of recognition as police, which is not necessarily 'the state apparatus of order keeping' but is a means of 'partitioning the sensible' (c.f. Pirsoul, 2017). When distributing parts in its sensible conception of democracy in the quest for consensus, the police neutralises dissent. By allocating parts, it excludes those with no part and ignores the voiceless as noise. It allows participation at the same time as excluding. Rancière (2010) illustrates the role of the police empirically with an example of a demonstration. The role of the police (logic) is not to listen to the demonstrators but to break up the demonstration. Rather than Althusser's (1971) 'Hey, you there!' which seeks and creates a political subject, it says 'Move along! There's nothing to see here!' which reduces the voice of that political subject to noise. It does not count the uncounted demonstrators. The governance of the 'police' order is therefore based on 
a logic of hierarchy which always works to preserve existing orders of inequality. However, the police order can give dissent more or less room, and oligarchic governments can be more or less democratic (Rancière, 2006). The democratic State is therefore limited by the dual recognition of popular sovereignty and individual liberties (Rancière, 2006). The police order seeks to co-opt dissent, for example Indigenous sovereignty struggles (Ruckstuhl, 2017) or human rights assertions (Li and McKernan, 2016), into the existing order to neutralise that dissent to reach consensus. Claims previously not sensible, become sensible through dissent. These acts of dissent based on demands for equality are what Rancière $(2006 ; 2010)$ distinguishes from police as politics.

For Rancière $(2006 ; 2010)$, politics is about counting the uncounted. Creating a space where rather than 'moving along', subjects are made, the uncounted can be counted and the voiceless can shout and be heard (Rancière, 2010). Politics reconfigures that space, or that demonstration, as a dispute over what is sensible. In contrast to Rancière's conception of the hierarchical police order, he sees politics as occurring when demands for equality, often through dissensus, are made. This requires a necessary break from the logic of arkhe (Rancière, 2010). These demands occur outside of the systems represented and distributed by the police order, and are necessarily always "antagonistic to policing" (Rancière, 1999, p. 29, as cited in Li and McKernan, 2016). Politics is therefore not efforts made through the institutions and mechanisms of the State but the interruption of those institutions - dissensus. This dissensus is often an expression for equality of anyone and everyone and is antagonistic to any institution based on hierarchy. When the logic of equality confronts the logic of hierarchy then this moment of dissensus is the political (Li and McKernan, 2016). Politics is not about opposition between groups with different interests, it is a conflict between the logic of who and what is counted as a part of the community. Bond, Diprose and Thomas (2019) suggest that the very possibility of dissensus emerges from an assertion of equality, and so by focusing on articulations of equality in particular contexts, we can better understand how more democratic moments of dissensus can occur.

It is important to recognise in moments of dissensus that it is not only the issue or interests being argued over, but also the lack of recognition as a "'speaking being' equal with 'every other'" (Rancière 1999, p. 30, as cited in Ruckstuhl, 2017, p. 37). Every individual act of dissensus contributes to the ongoing project of what Rancière refers to as subjectivisation. This process of being heard as a speaking subject, with legitimate claims and a legitimate right to voice these claims is the essence of democracy. This dissensus creates the breakthrough of understanding required for all to recognise, problematize and rectify an existing inequality. If a particular speaking subject voices a wrong done to them, be it from an Indigenous, environmental, feminist, or any other perspective, this wrong is not only done to them but is a wrong against the equality that makes up the fundamental basis of democracy. If every actor strives for equality, then a breach of any other particular actor's equality is a breach against universal common equality. A breach of democracy. This takes the wrong out of the specific domain of the State to rectify and takes it into the hands of the democratic subjects. Where police logic would misidentify particular demands as specific to 'pressure groups' which can be managed within current systems, politics recognises the universality of any breach of a particular equality as a breach of universal equality (Ruckstuhl, 2017), thus rendering particular grievances relevant and interrelated to all others.

Rancière (2006) argues that the democratic process implies that dissenting actions of individuals or groups, acting between identities, reconfigures the distributions between public and private, universal and particular. The universal is often privatised by the police order in order to maintain the status quo, to protect the purity of public life, but a recognition that the universal is simply made up of constant re-articulations of the particular (see also Laclau, 2000) works to preserve this democratic process from the police order. Real democracy, according to Rancière, is thus where liberty and equality are not represented and protected by the law and institutions of the State but are "embodied in the very forms of concrete life and sensible experience" (Rancière, 2006 p. 3).

Dissensus emerges out of this discussion as a key mechanism for democratic accountability because it is the means through which the demos can be heard as having a political voice or demanding a stake as a stakeholder (Brown and Tregidga, 2017; Ruckstuhl, 2017). Rancière points out that democracy is the action that constantly wrests the monopoly of public life from oligarchic governments (Rancière, 2006). If we follow 
Rancière's underlying logic, we see that the 'normal' (problematic) evolution of society is a progression from government of birth to government of wealth, but politics (through dissensus) is the disruption of this order of things where political subjects insert forms of inscription that (ac)count for the unaccounted (Rancière, 2010, p. 35). That the 'part of those without a part' exists at all is the very stake of politics itself and politics is not necessarily about different interests but arises against the logic of counting parts in different ways (Rancière, 2010).

Dissensus towards demanding a part can therefore be seen as synonymous with demanding democratic accountability as a recognised stakeholder - demanding a stake. Indeed, Brown and Tregidga (2017) argue that the central question at stake in democratic theory is who can speak, when, in what capacity, for whom, with what legitimacy and in what tone (p. 1, following Norval, 2009). Consensus oriented engagement has failed to address challenges associated with speaking and being heard within non-hegemonic arguments (Brown and Tregidga, 2017, p. 2). Here what is at stake is the distribution of stakes, and according to Brown and Tregidga (2017), Rancière (2006; 2010) highlights the role that emergent voices and un-reasonable people play and can play in creating new social realities and identities. They suggest that a focus of social and environmental accounting research could be to count who takes part and who does not in demands for accountability, and that is what this paper sets out to do. This can involve highlighting dissensus outside of the police in demands for accountability and a stake, or at the edges of police logic itself because dissensus recognises that there is always unfinished business in the demand for democratic accountability (Brown and Tregidga, 2017).

Politics, in short, disrupts the "normal(ized)" order and produces new social realities. It occurs because those who have no right to ac/count "make themselves of some account" (Rancière, 1999, p. 27) through their assertions of equality (Brown and Tregidga, 2017, p. 4).

As Rancière (1999; 2006; 2010), and subsequently Ruckstuhl (2017), Li and McKernan (2016) and Brown and Tregidga (2017) have shown it is dissensus that creates democracy. The act separates police from politics and constant and persistent demands for equality lead to constant and persistent reconfigurations of the relationship between the State and democratic citizens. Thus democracy is not "a fixed state of being but a state of becoming" (Ruckstuhl, 2017, p. 38, following Rancière, 1992). We explore this idea in an empirical setting surrounding an initial dispute over petroleum exploration, which transformed into a dispute over who is counted in democratic processes. This work builds on prior literature by exploring diverse practices of giving and demanding democratic accountability from within police systems and outside of these systems (politics) through a Rancièrean lens (Rancière, 1992; 1999; 2006; 2010). This leads to the research question for this study: how is democratic accountability exercised in the deep-sea petroleum exploration of Aotearoa New Zealand?

\section{Research Methods}

This study can broadly be considered a case study (Stake, 1995; Lee and Saunders, 2017). Although the boundaries are more difficult to define than a single organisation, the case is organised around a particular phenomenon (deep-sea petroleum exploration) in a defined area (South Island of Aotearoa New Zealand). The nature of this case study is intrinsic and emergent (Stake, 1995; Lee and Saunders, 2017). Its intrinsic nature means that we seek to understand the dynamics of this case and not necessarily for instrumental reasons to understand other phenomena. We want to understand the particularity and complexity of this case and there is a possibility for naturalistic generalisations to be made but they are not our primary motivation (Stake, 1995; Llewelyn and Northcott, 2007). Its emergent nature suggests that the case study developed throughout the research process as the researchers encountered new circumstances and ideas which were often unanticipated (Lee and Saunders, 2017). By doing this, we hope to explore and explain a concept (democratic accountability) in a specific setting (Llewelyn, 2003: Guthrie and Parker, 2017). Empirical materials were collected through semi-structured conversations (Walton, 2007) with key actors engaging within the case as indicated in Table 1 . These were supplemented by reviews of documentation and media to provide context. 
An extensive media analysis was undertaken prior to interviews. This was necessary to sketch out the case and its participants, develop themes for the semi-structured conversations and gain an understanding of the wider context of the case. For this the Factiva Database (Factiva, n.d.) was used. The keyword in the search was "Anadarko" (because this organisation and its exploration vessel held the permit for oil and gas exploration off the coast of the South Island) and the time parameter was 26 July $2011-26$ July 2014. The Factiva database includes the majority of large commercial New Zealand print and online newspapers, national and regional. This returned 391 unique results, some of which were duplicates with small changes.

Template analysis (King and Brooks, 2017) was used to identify emergent themes and sketch out who the participants were. Interested actors were identified and contacted based on this analysis. This process proved invaluable to develop the context of the case as well as constructing interview themes prior to fieldwork and allowing the researchers to be able to conduct more detailed and informed discussions with participants. This ensured that the time and energy which the participants were gracious enough to share with us was valued and put to its best use. In addition, there was a requirement for Māori consultation (University of Canterbury, n.d.) to ensure that the research was going to be conducted in an ethical and useful way for Māori participants. This proved invaluable in not only ensuring the research was ethical and useful from a Māori perspective but also added significant value to the direction of questioning, participant identification and feedback mechanisms. Finally, one of the researchers attended a number of demonstrations, marches and organising events as both a participant and a declared researcher. This was useful for further emic contextualisation as well as participant identification and contact.

The semi-structured conversations heard the stories of the conflict (Walton, 2007), and provided accounts of insiders' interpretations of the context (Phillips and Hardy, 2002). The guide to the conversations was emergent and subject to ongoing flexibility as each conversation occurred to include novel themes (Horton, Macve, and Struyven, 2004). In general, the guide included talking points on:

- Perceptions of benefits and risks of deep sea petroleum exploration as well as what others might consider these to be.

- Reflection on how the participant has engaged in this conflict.

- What accountability means to the participant, how this played out in practice and how it could be improved.

- The participants' responsibility in this engagement.

- Any other interesting points the participant might consider important.

17 unique conversations were conducted - 16 individual conversations and one group conversation. The conversations were conducted between December 2014 and March 2015 around Aotearoa New Zealand and lasted between 30 and 90 minutes each. Interviews were audio recorded with the permission of participants and transcribed in full by the lead researcher for thematic template analysis (King and Brooks, 2017). The majority of these actors were willing to be acknowledged by name and have their comments attributed to them, but to protect the identities of those participants unwilling to be acknowledged pseudonyms were given to all participants. We worked together to come up with suitable role descriptions. Participants were given the option to review and confirm quotes and ideas attributed to them. Email was the main form of initial contact. Every potential participant but four responded, and interviews were arranged if both the researcher and the participant felt it was necessary at the time. A government agency representative suggested other more appropriate contacts, two industry participants, one industry supporter and one iwi representative did not respond. Where it was not possible to organise an interview, secondary sources such as news media, legislation, Hansard and industry/government publications were explored. This enabled us to attain a comprehensive view of different perspectives throughout the case.

A number of novel themes emerged during template analysis, including a number of themes not engaged with in depth within this paper. These include risk, risk communication, evidence traps, kaitiakitanga (guardianship), and accountability of the self. While these themes contain important implications, they were seen as secondary to the three themes engaged with in this paper: consultation, partnership and dissensus. These were both pervasive throughout empirical materials and intimately interrelated with one another and relevant literature as alternative approaches to democratic accountability. Because this case was emergent 
and intrinsic, analysis took an abductive approach. Literature was engaged with before, during and after the template analysis and these three themes emerged as the dominant findings to contribute to understanding the theoretical and empirical implications of the study.

It is important to acknowledge the researchers' role in the case. By engaging with actors and asking a particular set of questions, the researchers effectively became actors situated in the case (Myers and Newman, 2007). Because of this, the knowledge creation process was to a certain extent emic (Stake, 1995) with the researchers reflecting on their own experience in the deep-sea petroleum exploration conflict during the collection, analysis and dissemination of empirical materials (Alvesson and Skoldberg, 2000). The lead author is also Ngāi Tahu who are tangata whenua (people of the land) of the affected area which creates another emic layer of knowledge production and relationality with participants.

\section{Contextualising the case}

Deep sea petroleum exploration is a novel activity for most areas of Aotearoa New Zealand and since the Deepwater Horizon (Babcock, 2012; Windsor and McNicholas, 2012) and Rena (Robson, 2012) disasters, the spectre of an oil spill, along with scientific consensus on the climate crisis have become significant points of contest. Between 2010 and 2017 the Government of New Zealand pursued an aggressive petroleum exploration programme to "unlock New Zealand's petroleum potential" (Former Prime Minister Key) (2010). Out of this aggressive pursuit, arose several issues for dispute, the first being the activity itself, the second being how voices were counted in engagement around that activity. It is this move from the former to the latter which presents a useful case for examining democratic accountability through a Rancièrean lens. Dissensus over who counts in decision-making around deep-sea oil became the issue at stake, rather than necessarily the activity itself. The 'partnership' bond between the Government of New Zealand and the Indigenous Peoples of Aotearoa New Zealand, Māori, provides a unique basis for this study. However, since the exploration companies operating in the region are multinational, petroleum exploration is not just a local engagement; actors from across the country and globe become involved. In this section, we outline the role of the Government in deep-sea petroleum exploration; opportunities for public participation in decisionmaking and the partnership relationship between Māori and the government of New Zealand. We do so to give a brief but necessary context to the case in question and the police-politics implications for democratic accountability within deep-sea petroleum exploration.

The Crown Minerals Act 1991 governs the management and use of 'crown-owned minerals' which include petroleum in New Zealand's Exclusive Economic Zone (EEZ) as well as on land. The purpose of the Act is "to promote prospecting for, exploration for, and mining of Crown owned minerals for the benefit of New Zealand" (s. 1A). Since its original drafting, the Crown Minerals Act 1991 has had a number of amendments, the most controversial being in 2013. On 9 April 2013 the Minister for Energy and Resources used a postSelect Committee supplementary order paper as a portal to rush a controversial law change (Davison, 2013). This change provides powers of enforcement to stop a ship; remove any person from a ship; or prevent someone from entering a ship within a specified non-interference zone; or without warrant, arrest a person who has committed, or is attempting to commit an offence against provisions in the Act (NZ Parliamentary Library, 2013). This amendment was justified by particular actors as a safety measure, and to protect property from damage (Davison, 2013). By others it was condemned as a "sledgehammer designed to attack peaceful protest at sea" (Davison, 2013).

This amendment generated a large amount of media attention, one reason being that New Zealand has a long history of peaceful protest - from early women's suffrage; to the Māori Land Marches in the 1970s; to the anti-apartheid demonstrations of the 1980s; and protests at sea against nuclear testing in the late 1970s and $80 \mathrm{~s}$ (Ministry for Culture and Heritage, n.d.). This history of civil society resistance and dissensus in relation to transforming structures of society is an important consideration in the examination of the current conflict. These acts of dissent are repeated again and again, and this to Rancière, is the democratic process. The clash between State/police and the outsiders demanding a seat inside. The voiceless demanding a voice. The rightsless demanding rights. Through a Rancièrean lens, this legal amendment was a strategy to 'move 
along' this history of political dissent from the seas and the publicity this gets, to the police mechanisms of the democratic State.

At the same time, opportunities to participate in police systems were being eroded. Until 2011, New Zealand did not have formal legislation governing activities in its EEZ. The purpose of the Exclusive Economic Zone and Continental Shelf (Environmental Effects) Act 2012 (EEZ Act 2012) is "to promote the sustainable management of the natural resources of the exclusive economic zone and the continental shelf" (s. 10(1)). Under the Act, petroleum exploration is classified as a non-notified activity which means that an application for a marine consent is not publicly notified, so long as certain regulations are met. The EEZ Act 2012 decreased the opportunity for official police-sanctioned participation in the decision-making process around deep-sea petroleum exploration and the 2013 amendment to the Crown Minerals Act 1991 reduced opportunities to participate in dissensus politics. As will be discussed in the next section, this led to bottomup innovations to engage in both police mechanisms and political dissensus (c.f. Bond et al., 2019).

Māori play a unique and crucial role in this case. Ruckstuhl (2013) suggests there are three ways Māori engage with extractive industries: as an economic opportunity (given appropriate environmental safeguards), as an environmental issue and as a discussion around Te Tiriti/Treaty rights. Te Tiriti/Treaty rights refer to the rights of Māori under Te Tiriti/Treaty of Waitangi. This was signed in 1840 by representatives of the Crown and over 500 Māori leaders from around Aotearoa New Zealand (Ministry for Culture and Heritage, n.d.). Ever since, there have been frequent and recurring disputes over interpretations and breaches of Te Tiriti/Treaty. Under the Treaty settlement process, local and national bodies are required to consider, consult with, or include Māori in the development and delivery of public policy (Ruckstuhl, Thompson-Fawcett and Rae, 2014). Local and central government must consider the principles of Te Tiriti/Treaty and one essential principle is 'partnership'.

According to Ruckstuhl et al. (2014) "the partnership approach emphasises the continuing and on-going nature of resource usage that requires continual dialogue" (p. 306). According to this principle, Māori are partners of The Government of New Zealand in decision making and resource management. Because of this partnership, the Crown still requires consultation with Māori during a number of stages in the process around petroleum exploration and extraction. This gives Māori more 'voice' from a Rancièrean perspective than other actors in this case. After 150 years of struggling for formal recognition of Māori rights enshrined in the Treaty, many Māori groups know all too well the feeling of not having voice in State-democratic systems. These struggles for voice used both the recognised police structures of the democratic State as well as political dissensus (see for example O'Regan, 1991; Anderson et al., 2016). In our case study, various Māori groups empathised with other actors excluded from official mechanisms for accountability and invited these actors along to Māori consultation meetings. These groups recognised that a particular grievance against the equality to be heard was a universal grievance against equality, and moved to rectify that. This is discussed in the next section.

This section has sought to contextualise the case in which democratic accountability is explored. In particular, it emphasizes the changing of formalities for engagement and how this interacts with Rancière's policepolitics framework. The cause for dissensus is not only deep-sea petroleum exploration itself, but also who is and who is not counted in the police-sanctioned decision making framework.

\section{Consultation, Te Tiriti partnership and dissensus}

This section focuses on formal consultations and submissions, Te Tiriti/Treaty partnership, and protest/dissensus, where the former represent police logics, the latter, politics, and Te Tiriti/Treaty partnership being a novel perspective in a settler-colonial context that advances within and beyond Rancière's police/politics distinction. Overall, these findings suggest that in this case the limitations in the police framework, including a reduction in opportunities for democratic accountability, resulted in increasing dissensus which moved politics from engagement around the specific activity - deep-sea petroleum exploration - to demanding a part in the process itself. At the same time, the approach taken by Māori in 
their engagement with citizens, the State and corporations opens up new territory for exploring democratic accountability.

\section{Consultation and submissions}

It was noted in the previous section that opportunities for democratic accountability within the police framework were being eroded in regards to this specific activity, for example the non-notified status of relevant legislation passed. In response, the aspects of the police framework that were more democratic, that is Māori consultation and local government submissions, were opened up to the public to fill the democratic deficit. This supports our response to Brown and Tregidga (2017) to examine aspects of the police framework that are more open to democratic accountability.

According to an opposition MP, Wendy, who sat for a short time on the select committee overseeing the Exclusive Economic Zone (EEZ) legislation, "communities need to have input into what happens in their area, and the EEZ legislation really hasn't allowed for that to happen." Another opposition MP, Sarah, argues that, extensive public input is required for this activity "because the seas are a commons, and with these prospecting applications, the public haven't been able to say 'what happens to our sea?"' Because of this non-notified status and the 'partnership principle' discussed above, the key engagement between Government, industry and the public was during iwi consultations on marae (formal meeting places central to Māori cultural identity) and local government council submissions. This is because a number of iwi groups and councils recognised that public opportunities for the holding to account were being shut-down and so consequently opened up their processes to the public to counter this reduction in engagement. The opportunities to participate within Rancière's police were reduced, and as a reaction bottom-up coalitions and participation opportunities were born.

In this particular case, however, the consultation processes discussed were referred to by iwi members, councillors, local business and activists a like as 'a fait acompli', 'monster out of the bag', 'lip service', 'box ticking', 'a public relations exercise' and 'an outsourcing of the Government's partnership responsibilities'. Nonetheless, some felt that the process was relatively empowering, despite not getting exact outcomes, and it depended on where and when the consultation happened during the process. Sam, a climate campaigner wanted to "feel like I was being listened to, and any concerns at all were even being listened to." Pam and John, tourism operators in Kaikōura, attended an iwi consultation with Anadarko and representatives from the Government on the Takahanga Marae [4] to ascertain the benefits for the region from petroleum exploration. During the meeting John just wanted to ask "well hey, it's too late, we've let the cat out of the bag, why are we having these meetings now when the Government has already decided that these guys can go ahead and do that?" The impression that Pam got was that "they're doing it because they have to, not because they genuinely care about any given community." A Government regulator reflected on these consultations based on their experience "we gave the public the opportunity to question, and to be quite frank not many people turned up... I suspect what you're hearing is what the media portrays which is based on a minority of vocal people." Graham, a prominent industry representative with a background in community engagement, provided the industry's point of view on consultation:

The consenting regimes are generally seeking to have [government and industry] people talk to communities, and even if they weren't... Well best practice would indicate that they would. If you lose the trust and confidence of the communities in which you operate, you'll be pretty short lived. Our industry really values that (Graham).

From Graham's perspective, consulting with the community appears to be just as important for industry as it is for community "it is crucially important that communities feel like they're a part of what is happening rather than things are being done to them. It's crucially important". This would seem to confirm much evidence in the extractive industries that a 'social license to operate' is increasingly essential for organisational survival (e.g., Prno and Slocombe, 2012; Ruckstuhl et al.,_2014). In our case, industry response was consistent with engaging above and beyond the level required by the police mechanisms in order to preempt escalations in political dissensus. However, is it the industry's job to consult with the public on what 
they are going to do in place of the Government that represents that 'public' and protects their interests? Several of the actors we spoke with thought it was a buck passing activity.

I don't think that it is the company's job to consult with the community. I think that there's a step that has been missed, which is a conversation between the Government and its people about whether or not an activity is appropriate or right in a community (Mary, a city councillor).

To counter this, iwi groups invited the public onto marae for consultations (see Pam and John above) and Mary and other councillors up and down the country opened their council submissions to the public. The open council submissions have resulted in continual, formal opposition from city councils in Christchurch and Dunedin and for the first time in 2016, Auckland (Loughrey, 2016). "We felt that by opening it up to the public, and by undertaking to append all their submissions to our submission, it was a way of us saying to the Government 'well you're not talking to the right people'" (Mary). Fran, an oil-free activist appreciated the opportunity to be able to voice her concerns via the council. Fran got "the kind of transparency from our city council that we needed to have from our Government. Taking input from the public on important issues like this showed that our council are sincere in their representation of the public's interest." This is an example of different relationships of accountability being established within the case as actors experience and adjust to changes in participation opportunities.

These adaptations support Rancière's caveat that police logic can be more or less democratic. Although city councils are seen as part of the police logic, these councils made more room for participation in their consultation and submission process and formally opposed the actions of the Government of New Zealand. In this way, these councils were pushing the democratic limits of the police logic which Rancière refers to. Public participation was pivotal in amending the councils' submissions to the central Government, but these submissions do not seem to have been pivotal in the Government's decision to offer blocks for tender (New Zealand Petroleum and Minerals, 2017). Indeed, another city councillor, Beverley, made the comment that she "gets the feeling that this is going on regardless... you must do them over Christmas, and the last one was just at the time of the elections.... I mean it's superb timing if you don't want local government input." The potential consequences of this were synthesised well by Sarah:

Seeing all the energy that got put into submissions on the EEZ legislation, and a large number of those being ignored.... It's a misuse of the process and it breeds cynicism. People put all that energy in, they're not listened to and so people think "why should we even bother?" And so people don't engage, but the corporates always engage so their views tend to prevail (Sarah, an opposition MP).

Here we have seen aspects of the police framework being closed down and other aspects of it which are more democratic being opened up as a response. Despite this, the police-sanctioned submission and consultation processes that remained were found to be wanting by some of those spoken with. The longterm consequences of this were pointed out above by Sarah, that deliberate reductions in opportunities for participation in democratic accountability, in addition to a watering down of remaining mechanisms, could lead to disenfranchisement. One of the aspects of formal engagement that was opened up was Māori consultation which is an obligation under the Treaty. It is this obligation that we turn to next because it provides a phenomenon for exploration that does not sit as comfortably in Rancière's police-politics distinction.

\section{Treaty partnership}

The most unique aspect of this case is the partnership principle that exists as a result of Te Tiriti/The Treaty of Waitangi between Government and Māori. This has not always been the case, and this obligation was ignored by the Government of New Zealand and other organisations for generations. This principle is only now starting to be exercised because of generations of dissensus through resistance by Māori taking a part for themselves, as well as engagement within the institutions of the Crown. Although Māori have opened up their consultations to the public to fill a democratic deficit, we can also see that the official Crown processes 
for engaging with Māori contradict a Treaty partnership. Specifically, these systems do not necessarily accommodate self-determined Māori processes of accountability. The implication of this for Rancière's thought is that democratic visions exercised under Indigenous authority can present alternative imagining's for democratic accountability that do not fit neatly into his police-politics framework.

Referring to the Government's partnership obligations with iwi, Rachael, a Māori academic engaging with the mining industry, argues that "what I think they're doing is outsourcing their responsibilities." An important question to ask is what do these engagements mean for the affected iwi groups? According to Rachael, it is not just about having a meeting, it is about "meeting them [industry and government] to understand why we would want to engage and what elements that we want them to really understand about us. This is not about giving position, this is about deciding where the line is for us." Here, local iwi were asserting their authority as legitimate partners in the governance of particular regions according to Te Tiriti. However, rather than the Government, and its ministers and officials formally engaging with iwi as partners, police mechanisms were being outsourced via individual companies and occasional agency representatives.

Graham, the industry representative, was able to provide an explanation of the necessity of iwi engagement and consultation from the industry's perspective. Using an example of training iwi representatives in marine mammal observation, he argued that "rather than pay lip service to people," the industry can "actually try to tangibly make a difference, actually do something that is meaningful for them." He referred to this as a "tangible expression of kaitiakitanga," which can be taken to mean an industry perspective of enabling Māori to actively participate in the guardianship of territories. We asked Rachael for her opinion - as an academic who represents her rūnaka (local Māori council) - on whether partnership and kaitiakitanga were present, or enabled during this consultation process. She answered that it is a lot more complicated than this simple question, but that this particular process was not partnership. The iwi's partners are the Government. "Our partners are not oil and gas companies so we just need to be clear that there's a distinction there. The Crown puts it onto its agencies to say "how can we show that we are a partnership?"'

But within Māori groups, there are often different layers of authority and self-determination which do not necessarily align with police accountability mechanisms. For example, according to Rachael, the central governance table of local iwi:

Te Rūnanga [o Ngāi Tahu] has a unit within it that coordinates responses to government submissions. There is NO attempt by Te Rūnanga to say 'this is the party line.' Everybody can have their own view but we want to tell you what we're doing

Because of this, for Serena from Kaikōura, "the process, I think, was too swift, not enough time, and we tend to do submissions as a hapu and as a tribe." There can often be "information coming through that you couldn't understand, no time to review it or to get around and talk about it." Serena talks about the importance of having time to come together to make decisions for submissions and consultations. Especially for something like this, which Serena considers "a big Ngāi Tahu issue." "In Ngāi Tahu we don't have a standard 'this is Ngāi Tahu stance' because our West Coast whānau [family] have been mining for years so they see mining in a different light." "We brought everyone to the party to try and understand, to try and have a conversation with the Government and with Anadarko... but we needed huis [meetings] before then." But Serena has a suspicion, which was shared by city councillors in their submission and consultations that in this case "I think it was probably purposely done that way so we couldn't get ourselves organised and together." This suggests that the police mechanisms of accountability allowed for and controlled by the Government of New Zealand do not always align with Māori expressions of self-determination and accountability within these.

In addition, if the Crown has not consulted with iwi as a partner at the outset then every single company must do this, every single time, with every single iwi. "Our rūnaka [council], like a lot of hapū and iwi up and down the country, has been bombarded with requests for engagements with oil and gas companies for about the last five years" (Rachael). Graham, the industry representative provides an explanation as to why the engagement process may be more of a burden to some iwi than an opportunity. "For iwi, engagement with a petroleum company is one of $20,30,50,100$ things on their agenda." He even followed up some weeks 
later about having mulled over this exact point. "I am mindful of the responsibilities that these groups feel to engage and project their values and aspirations, but often with the scarcity of resource to do so." Serena supports this sentiment. "We are very short on people resources, with people who are involved with the environmental area. That's the area that I have put all my energies into, and that's probably the area that our rūnanga is most active in." The Crown has transferred the responsibility to engage with communities and iwi to companies and regulators, after the inevitably of the activity has already been confirmed. This opens up a floodgate of consultation requirements for industry, regulators and iwi. These consultations require resources on all sides, and put a strain on the democratic process. Te Tiriti/The Treaty partnership requires significant resourcing on all sides, but with corporate actors and the State being significantly more resourced than iwi. This suggests there is a significant power and resource differential within the partnership which allocates more parts to some than others.

We asked Serena what could be done better to enhance this partnership. "Well if it could be demonstrated that they're actually listening to some of the issues... Whether I accept it or not is neither here nor there... I don't feel heard." Serena continues that "there have been individuals in this process who l've talked to, from Anadarko, and from the Government, who have been very, very nice people. Who I've felt have listened to me, but they don't have enough power" to make any tangible difference. Here, despite the partnership between the Crown and local Māori groups, a formal subjectivisation (Rancière, 1999) for Māori, Serena still feels like these systems of accountability do not give her voice. Sarah, an opposition MP, suggested that a reason for this may be that under the Government at the time, the Ministry of Business Innovation and Employment "has got even bigger, so it's much more difficult to influence. It's a bit like the titanic, a superliner, changing its direction is quite difficult." This issue was noted by Stewart (1984) who argues that the increasing complexity in government, and in effect police mechanisms, has created challenges for different forms of accountability. This has been a recurring theme throughout iwi engagements with the Crown.

The potential of Te Tiriti/The Treaty partnership to advance Rancière's thought is apparent. Māori, an Indigenous grouping in a settler-colonial context have fought for generations for the Government to honour its obligations under The Treaty that set out a future framework for the governance of Aotearoa New Zealand. That is, Māori spent generations demanding a part, now they have a formalised part in the process of democratic accountability and this historical context provides some nuance to Rancière's police-politics distinction. The partnership provides an alternative imaginary where two spheres of authority, Crown and Māori come together with different democratic accountability practices, but the practice of this partnership is still largely determined by the Crown. We argue that this partnership, if honoured by all parties, moves Rancière's thought forward conceptually, but in this case not yet practically. The part that Māori now have, however, may be more or less democratic within the wider police logics. When this part is not enough, politics through dissensus emerges as an alternative means for democratic accountability, because more parts must be demanded, taken and distributed.

\section{Dissensus}

During the course of the research there were several highly visible dissensus campaigns. Although not all of these were located specifically in the area of research, they were all directed towards operations which were occurring in the research region. The most significant being a hikoi (protest march or parade) from the far north to a petroleum convention in Auckland (Manning, 2014) and a flotilla (multiple small boats) occupying the site where Anadarko was planning to drill (Manning and Blockhouse, 2013). We believe it is important to explore what activists, as individuals and organisations aim to achieve from these acts of dissensus. While the dissensus was largely about specific outcomes and interests, that is, resistance against deep-sea petroleum exploration, dissensus was escalated when opportunities to engage in police mechanisms were shut down, and opportunities to stage dissensus in politics were also threatened. Dissensus was not just in regards to the activity, but in regards to having a part in the process. It was an act of subjectification. This aligns with Rancière's thought and reinforces the need to investigate dissenus in analyses of democratic accountability. 
Sam, a climate campaigner, discusses the hikoi, "We were just standing there, looking at them, like "who do you think you are? What do you think you're doing?' with this really strong sense of solidarity...... think they felt all that mana [prestige, authority] coming because we felt really powerful. It was a very empowering moment." Faye's participation in dissensus was motivated by a sense of responsibility "I was there on behalf of the whales and the dolphins, and the marine ecosystem. My responsibility is to protect those things that really matter in life... against big money, big oil and big industry". Although it is difficult to measure the impact of this in changing policy or behaviour, the affect it has on personal and collective perceptions of subjectivisation is clear. By making themselves and their dissent visible to the petroleum industry and Government, the activists were taking a part for themselves and others with none.

Pam and John who do not consider themselves activists "by any stretch of the imagination" felt let down by consultations so decided to attend a number of protests on the beach and provide high quality photos to activists for use in campaigning. Serena who often works within the system was anxious about engaging in vocal dissensus in case it affected other participation opportunities. Nevertheless, she also went to the beach to demonstrate. Serena suggests that "This was a good way to show that this is a peaceful, non-threatening, beautiful thing. To me that image was quite powerful. Families on the beach." Here we have examples of actors who have demanded and taken a part and prefer to work within systems feeling let down by those systems so joining in solidarity with activists to stage dissensus. And feeling empowered by that act of nonviolent direct action. On the flipside of this, Andy a seasoned climate campaigner also attended the official consultation on Takahanga Marae in Kaikōura and conveyed to the Anadarko representatives "You guys are going to have a real challenge on your hands because here New Zealanders care about their oceans and their coastlines very deeply and they don't want to see that risked." He used the police means of accountability as a mechanism to advise his adversaries of upcoming political dissensus. In addition to this, several opposition MPs and city councillors participated in marches and gave speeches during dissensus activities. These are all examples of the fluidity of actors moving in and out of police and politics activities when these are seen to be more or less democratic, and more or less enabling of different voices and parts.

One of the most visible acts of dissensus was a flotilla to block the exploratory drilling (Smallman, 2013). Faye was directly involved with the flotilla and shared her motivation for action:

We were protesting against the drilling, but we were also challenging the Government's crazy law which made it a criminal offence to go within 500 metres of a drilling ship. I mean we have a right of peaceful protest at sea. It's been really important in New Zealand's history. We need to hang onto that right. By asserting that right again we basically crumbled the law because they didn't enforce it. It [the amendment] doesn't mean anything now (Faye).

Here the protest was aimed directly at the company, but it was also about the broader idea of protecting democratic processes. This was a direct act of dissensus against the police logic trying to prevent political dissensus. The activists on the boat were not only making a statement that petroleum exploration without the consent of affected communities was a particular grievance but also that removing rights to participate in decision-making systems was a universal grievance against equality. It was an inegalitarian police logic worth struggling against. This political act of dissenus delegitimised the police logic which had removed the right to protest at sea. Recently, three activists including former MP Russel Norman were the first to be charged under the amendment (Boyack, 2017). Norman and fellow campaigner Sara Howell pleaded not guilty instead of taking diversion in order to challenge their charges and the amendment in Court. These are instances of new avenues of demanding accountability being explored as a direct result of rule changes in police logics. Faye and Russel tried to bring about change through police mechanisms, to the extent of being elected as members of parliament, but after several years inside this system, felt that acts of dissensus outside of these systems were more effective and more democratic. Actors in this case were creating new somewhat antagonistic - accountability relationships because they had been shut out of police processes. This is why it is important to consider the critical role that social movements play in demanding and transforming accountability relationships (Catchpowle and Smyth, 2016) and Rancière's thought enables this. 
Regarding this act of dissensus, Minister for Energy and Resources at the time, Simon Bridges stated that he "absolutely" supports the democratic rights of people to protest but "I think what's important is it has to be safe and it shouldn't interfere with other people's lawful rights" (Taranaki Daily News, 2013). Anadarko's New Zealand manager, Alan Seay claims that: "We respect their right to protest and I'd ask that they respect our right to go about our lawful business and respect the safety zone that will be around the Noble Bob Douglas," (Smallman, 2013). "We are going about our business. We are getting ready to start drilling in a day or two. They can't hold a position. They are a sail boat." (Gardner, 2013). So here dissensus is accepted as democratic by supporters of the industry as long as it is within prescribed limits of safety assigned by police logic. The police logic seeks to unilaterally determine the parameters of dissensus politics, but, of course, it never can in totality.

The day the flotilla arrived back to shore, Greenpeace NZ filed judicial proceedings against the Environmental Protection Authority (EPA) to challenge the process which gave Anadarko permission to drill (Manning and Blockhouse, 2013). Justice Mackenzie held that "a decision which is 'wholly administrative in nature' and 'essentially mechanical' is not readily susceptible to the sort of error which may justify judicial review" (Greenpeace of New Zealand Inc. $v$ The Environmental Protection Authority, 2013, p. 12). In order to succeed on this application Greenpeace NZ must demonstrate that there has been an error in law on the part of the EPA. This is a further example of how groups demanding voice and rights will do so by any means necessary, through dissensus politics, or within the police systems. Rancière (2006) suggests that all politics is antagonistic to police logic but also that the State can be more or less democratic. Greenpeace NZ (and other groups) challenged the drilling through an act of political dissent at sea as well as through the judicial system, thus engaging in police and politics where they believed it best suited their objectives.

In this case there are two primary motivations for staging acts of dissensus. The first is against the activity itself and the risk of spills and threat of a contribution to the climate crisis. The second is subtle but is more in line with Rancière's thought and has implications for democratic accountability more widely. This is the staging of dissensus towards demanding a part where police opportunities for participation have been shut down, and those same police logics minimise and move along political dissent. This reaffirms Rancière's contribution that police logics towards demonstrations are not immediately to 'recognise' the demonstration but to 'move along' the dissensus. In our case, this extension of police logics towards regulating dissensus led to more dissensus springing up in new forms as citizens and groups demanded their part through peaceful protest at sea. Although dissensus is not commonly associated with an accountability process, it is necessary to consider it as part of a broader framework for democratic accountability where those with no part can take a part, and be recognised and considered within police systems of accountability. Staging dissensus is a key aspect of maintaining and demanding democratic accountability. That is, dissensus is an instance of demanding accountability from below. We turn to discussing this in the next section.

\section{Discussion}

Democratic accountability is multifaceted in this case and participants value the democratic forum as much as, if not more than, the accounts distributed within the forum. We believe that the radical potential of accountability - as a tool for demanding equality - lies in the forum for accounts in addition to the provision of accounts (Stewart, 1984; Greiling and Spraul, 2010). By privileging the voice of a diverse array of actors within the case, our findings suggest that the desire to feel like they had a speaking part that was being listened to is a pivotal motivation. It was about actors feeling that they were considered, that they were valued, that they were partners; that they were part of the process of accountability. They desired a part in the count (Rancière, 2010). Democratic participation has been closed down in the police framework around deep sea petroleum exploration, and this has sparked significant political dissent. This resistance, a response to a closing down of accountability mechanisms, has emerged as an alternative, outside of the police mechanisms within the case, to demand and transform accountability relationships. The political dissensus is therefore a form of demanding democratic accountability in its own right and should be recognised as so. Being excluded seems to be regarded as a fundamental instance of unaccountability. But voicing dissent at this exclusion is also a fundamental instance of reclaiming democratic accountability (Rancière, 1999). 
This paper contributes to the literature around democratic accountability by drawing from the advances made by Li and McKernan (2016), Ruckstuhl (2017) and Brown and Tregidga (2017) who all engage with the thought of Jacques Rancière and the democratic moment. Specifically they have extended our understanding of democratic accountability by reconceptualising politics as inclusive of dissensus. The theoretical implications of our case confirm this perspective and suggest that when opportunities for democratic accountability within the sanctioned police order are reduced, then new relationships within politics through dissensus will emerge as a response. Democratic citizens will demand democratic accountability. We therefore advocate perspectives which incorporate and explore dissensus as a mechanism for the demanding of accountability. In addition, the partnership relationship between the State and Indigenous Peoples provides a novel opportunity to examine different perspectives around democratic accountability. In our case, Māori engaged in democratic accountability in different ways to non-Māori and the State, and developments in partnership relations overtime reflect this and therefore contain novel ideas.

In our case, individuals and organisations moved fluidly between police and politics mechanisms in their pursuit of democratic accountability and these mechanisms adjusted and readjusted accordingly. It is at this point where it becomes necessary to extend (or dilute) Rancière's analysis for the purposes of this paper. Brown and Tregidga (2017) point to previous critiques of Rancière which say that he draws too sharp a division between politics and police, despite his own historical examples illustrating how in some cases 'the counted' respond or learn from new demands by 'the uncounted' (Norval, 2012, p. 817, as cited in Brown and Tregidga, 2017). Although Rancière does take pains to emphasize that one police order can always be more preferable and 'more democratic' to another, he stresses that "whether the police is sweet and kind does not make it any less the opposite of politics" (Rancière, 1999, p. 30-31, as cited in Brown and Tregidga, 2017). This is where the constant strive for equality of voice splits from the constant strive for equality of particular outcomes and is also where our analysis departs from Rancière. Following Ruckstuhl's (2017) paraphrasing of Rancière, we argue that democratic accountability is a state of becoming. The evolution of the partnership between Māori and the State suggests more nuance is required in any empirical analysis of democratic accountability and we turn to this next.

Each political challenge to the social order lays down inscriptions of equality to provide guidance for future claims and action (Li and McKernan, 2016). This develops a progressive and positive dialectic where the social order can become 'better' and more open to alternative ways of being and doing through successive acts of dissensus. In their case, the political progress of rights is not necessarily a steady accumulation of progress but a history of particular solutions to the dialectic of equality and inequality. As these inscriptions are institutionalised they can lose their emancipatory potential but can also be revived in new struggles ( $\mathrm{Li}$ and McKernan, 2016, following Deranty, 2003). As power is accumulated in police, resistance is also accumulated in politics (Estes, 2019).

Following McKernan and Li (2016) we have examined a case of a historical dialectic of particular demands for equality in the process of democratic accountability overtime, which more generally opened up space for democratic accountability within the police order. Indigenous struggles for sovereignty create space for the Treaty to be honoured through partnership, and the alternative imaginaries of democratic accountability developed in this new (police according to Rancière's analysis) space. Indeed, Norval (2012) urges careful attention to the openness of those that are counted to the demands of the uncounted in historical and contemporary cases and Brown and Tregidga (2017) advise us to consider, protect and extend the traces of equality found within the police order. Our contemporary case recognises the historical accumulation of demands for equality to open up parts of the police while other parts are shut down. It also invites us to consider temporal challenges to Rancière's police-politics distinction as colonial and decolonial dynamics play out over time. How does the disruptive logic from prior dissensus spread to contemporary and future demands for equality? As Ruckstuhl argues, although aspects of Indigenous sovereignty struggles have been co-opted and accommodated by police logics within the State, within this act of political manoeuvring, there has been a shift in what is meant by the democratic nation state itself in a settler-colonial context (Ruckstuhl, 2017, p. 37).

Li and McKernan (2016) and Brown and Tregidga (2017) do, however, present contrasting interpretations of Rancière's thought in action. Li and McKernan (2016) have no faith in counter accounts which they consider 
folk politics. They suggest that these accounts tend to focus on critique and are overly localised rather than brought together to drive emancipatory systemic change. They do, however, align their theoretical perspective with Laclau (2000) that the universal emerges through an articulation and re-articulation of particulars within hegemonic struggles (Li and McKernan, 2016, p. 572). Brown and Tregidga (2017) hold a more optimistic view towards counter accounts and their role in localised social movements. We suggest that the coming together of different localised struggles in our case, such as Indigenous sovereignty, climate justice, and demands for democratic accountability, can coalesce into a wider movement towards equality. Counter accounts, but specifically counter forums for the account, play a particular role in not only critiquing the status quo, but presenting alternative democratic imaginings. Indeed, Rancière argues that the focus on democracy as equality leads to any breach of any actor's equality as a breach of universal common equality - a breach of democracy. This takes a wrong away from the specific domain of the State and into the hands of the people as democratic subjects to rectify. We would ask, if not counter-accounts, counter-forums and 'folk politics', what are the mechanisms through which to operationalise Rancière's theoretical perspective in our current and future political realities? How should uncounted actors 'act out' to demand their part? Subjectivisation in Rancière's framework is where those with no part identify themselves as a particular group with a specific wrong, yet seek a universal truth to shift the playing field (Ruckstuhl, 2017, p. 38).

In our case the Māori land march, which can be considered a counter-account to gain recognition, indirectly led to the establishment of the Waitangi Tribunal and the Treaty of Waitangi and subsequent acts which began to formalise consultation with Māori as necessary to Treaty partnership (Ministry for Culture and Heritage, 2014). This relationship is looked at by other democratic nation states and Indigenous Peoples seeking to reconcile their relationship (O'Sullivan, 2017). It is also true that there were significant efforts within the police framework to make it more equal to Māori voice, and Pirsoul (2017) acknowledges these alternative Indigenous struggles for self-determination not as a binary of ideal-types but as a spectrum covering a wide array of political strategies (p. 253). Here, a particular counter-account, a march demanding a part in the count - led to an as yet seen but growing universal model for equality within police logics, and this reality is part of the wider analysis of democratic accountability in our case.

These perspectives give some credence to Brown and Tregidga's (2017) optimism around the potential for counter accounts in Rancière's framework, as a "staging encounter" where egalitarian logic confronts police logic. We suggest that not only are new selves and social realities cultivated through creative practices of counter-accounting as a means to stage dissensus (Brown, Dillard and Hopper, 2015; Gallhofer, Haslam and Yonekura, 2015; Brown and Tregidga, 2017; Vinnari and Laine, 2017), but so too are counter-forums. Alternative forums for accounts, for example the marae, can and have created new opportunities for democratic accountability at the intersection of police and politics and in doing so have created (or recreated) new social realities for democratic relations. Counter accounts and alternative forums can be used to "claim and test rights, highlight contradictions, dispute wrongs and stage dissensus over the way accountability is interpreted and applied" (Brown and Tregidga, 2017, p. 17).

As a post script to our study, the incoming Labour-led coalition, which now includes several of the opposition MPs interviewed in this study, placed a ban on issuing new permits for offshore petroleum exploration soon into their electoral term. Although we do not have evidence to directly link this to any sort of dissensus activity, this response was more in line with calls for dissensus than Labour's official policy while in opposition. In addition, following a report regarding the operations around the amendment to the 2013 amendment to the Crown Minerals Act 1991, which stated that the non-interference provisions were not a deterrent to interference but likely increased protest at sea (Murdoch, 2019), the Green Party, now part of the government have called for the amendment to be rescinded (Greens, 2019). It is clear that the dissensus being expressed within the politics of the coming together of these local movements across traditionally conflicting actors, is questioning the sensibility of petroleum exploration off Aotearoa New Zealand's shore. Demonstrating the fluidity of dissensus and police, the State appear ready to recognise dissent against both exploration, and reductions in democratic accountability, as a sensible position and co-opted this into its logics. Police logics are far from fixed and stable. 


\section{Concluding thoughts}

This research has confirmed the suggestions by Ruckstuhl (2017), Li and McKernan (2016), and Brown and Tregidga (2017) that the democratic thought of Jacques Rancière has significant potential for exploring democratic accountability in a conflicted empirical setting. Focusing on both the police systems of accountability made available by the Government of New Zealand as well as the political dissensus outside of these systems to demand a part has given us a more comprehensive understanding of practices of the giving and demanding of democratic accountability. However, these papers present contrasting perspectives on how the thought manifests into action. Our findings suggest a lean towards the approach of Brown and Tregidga (2017) who are optimistic about the potential for counter-accounts to articulate and create alternative visions for society. In our case, following Rancière, counter-forums are driving new elements for democratic society.

We see no reason why acts of antagonistic dissensus outside of police orders cannot coincide with acts of agonistic consensus or other acts within police orders simultaneously. These need not be seen as isolated binaries as they are often presented in the literature. In this case for example, Māori and environmental groups show us that engagement can happen at different levels and different times through their dual actions of dissensus outside of police systems as well as within them. For example, Māori struggles for selfdetermination have often included dissensus outside of police systems at the same time as political engagement through parliamentary and judicial mechanisms as we saw through taking to the beach to demonstrate while authoring submissions for the police processes. Likewise Greenpeace NZ protesting 'unlawfully' at sea, then coming into shore and taking the struggle through the Court system. This contributes to the literature by recognising both police and politics, in Rancière's conception, as fundamental to democratic accountability.

Critical and social and environmental accountants can contribute to research along these lines. There is an increasing trend towards exploring the use of social or counter accounts in acts of dissensus and this is welcomed. However, this work tends towards researching social movements rather than being - or at least working with - social movements. We agree with Cooper, Taylor, Smith and Catchpowle (2005) that social accountants can contribute to social change. Using social accounts as an example, Cooper et al. (2005) argue these need to be produced outside the market, or in this case the police systems, informed by theory and tied with contemporary struggles and social movements. Accountants can play a pivotal role in providing robust evidence and techniques to political struggles 'antagonistically' while continuing to advocate for changes within police logics to make them more accountable in giving and hearing parts and voice.

This paper has contributed to the stream of social accounting research by examining actors' diverse practices of demanding democratic accountability. During this examination we have discovered that theorising around accountability being about more than just the provision of an account is consistent among affected actors. It is about the holding to account and recognising the plurality of methods through which actors demand and transform accountability relationships towards demanding a part and alternative social and environmental outcomes. These methods include demands for accountability within the State-sanctioned processes as well as outside of those - the police and the politics. This develops an understanding of democratic accountability within a case of conflict. It has also uncovered the importance of recognising and embracing difference in decision-making processes, particularly emphasising the importance of Indigenous perspectives on democracy and accountability as exercised through Te Tiriti/Treaty partnership. Within this partnership lies the potential to imagine and create alternative visions for democratic society. At the same time, we need to embrace dissensus and demands for accountability towards equality as a powerful, pivotal, part of the democratic process (Rancière, 1992; 1999; 2006; 2010) [4]. 


\section{Notes}

1. See Jacobs (2000) for a discussion and history of Te Tiriti/The Treaty from an accountability perspective.

2. Ruckstuhl also happens to be on the frontlines of engaging with the petroleum industry in the site of research. See for example Ruckstuhl (2013) and Ruckstuhl, Gale, Carter, Ellison, Flack and Russell (2017).

3. The place where Ngāti Kuri gather to dialogue (Kaikōura).

4. As a brief epilogue, some significant political and economic changes have occurred between the time of field work, writing up and engaging in the review process. Most importantly, Anadarko has surrendered its permit to explore off the coast of the South Island citing low oil prices as the key determinant, although partners in the venture are considering continuing operations (Frykberg, 2017). In addition, New Zealand voted in a new coalition government (Roy, 2017). This coalition includes the Green Party of Aotearoa New Zealand who have a policy of no new coal, fracking or deep-sea petroleum developments (Greens, 2017). On the $12^{\text {th }}$ of April, 2018, Energy and Resources Minister Megan Woods announced that there would be no new offshore exploration permits issued (Radio NZ, 2018). It is worth noting that several participants in this research are now Government Ministers, so it will be of great interest to follow changes over time.

\section{Appendix One - Glossary of Māori terms used}

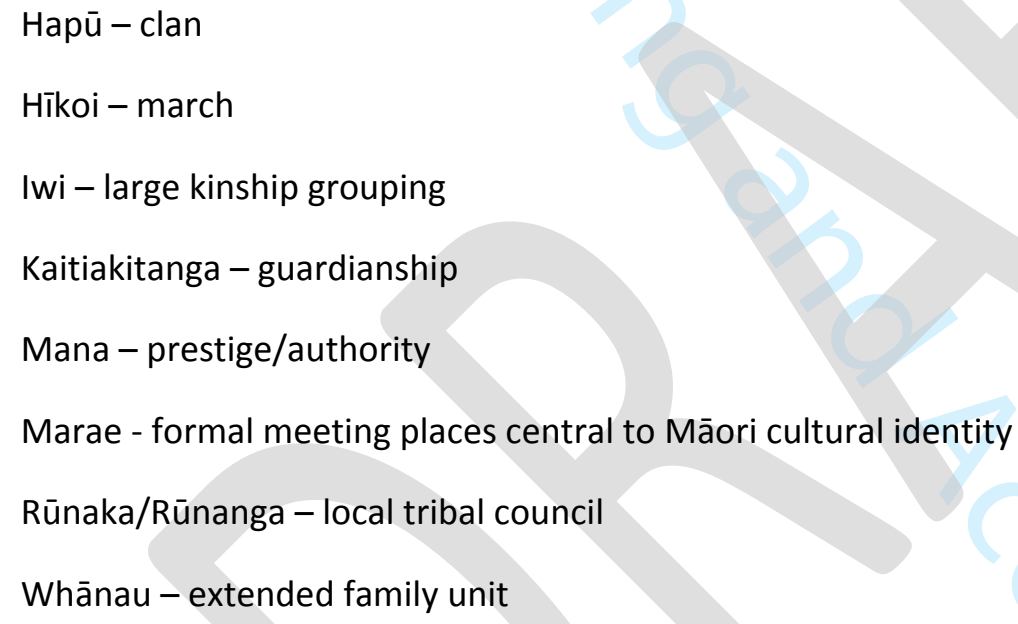

\section{Appendix Two - Interview participants}

Henry, Sarah and Wendy are opposition MPs involved in related policy areas

Sam, Faye, Fran, Yoshi and Andy are climate campaigners

Rachael is an academic who serves on a number of Ngāi Tahu and local rūnaka appointed boards.

Beverley and Mary are city councillors in affected cities

Serena is a resident of Kaikōura who identifies as Māori, and serves on a number of advocacy groups. Views are not representative of any rūnanga, iwi or other group that Serena is involved with.

Pam and John own a bed and breakfast in Kaikōura.

Harry is a senior business reporter for a media outlet in an affected region.

Mark and Phil are senior government officials involved in the industry

Graham is an industry representative 


\section{References}

Althusser, L. (1971), “Ideology and ideological state apparatuses (Notes towards an investigation)”, available at: https://www.marxists.org/reference/archive/althusser/1970/ideology.htm (accessed 25 February 2019).

Alvesson, M. and Skoldberg, K. (2000). Reflexive Methodology: New Vistas for Qualitative Research, SAGE Publications, London, England.

Anderson, A., Binney, J. and Harris, A. (2016). Tangata Whenua, Bridget Williams Books, Wellington, New Zealand.

Babcock, H. M. (2012), “A Risky Business: Generation of Nuclear Power and Deepwater Drilling for Offshore Oil and Gas", Columbia Journal of Environmental Law, Vol. 37, pp. 63-149.

Bond, S., Diprose, G., and Thomas, A. (2019), "Contesting deep sea oil: Politicisation-depoliticisationrepoliticisation", EPC: Politics and Space, Vol. 37 No. 3, pp. 519-538.

Bovens, M. (2007), "Public accountability", in Ferlie, E., Lynn, L. and Pollitt, C. (Eds.), The Oxford Handbook of Public Management, Oxford University Press, Oxford, England, pp. 182-208.

Boyack, N. (2017), "Greenpeace activists want their day in court over oil protest", stuff.co.nz, 21 August, available at: https://www.stuff.co.nz/national/politics/96206758/greenpeace-activists-want-theirday-in-court-over-oil-protest (accessed 18 December 2017).

Broadbent, J. (1998), "The gendered nature of "accounting logic": Pointers to an accounting that encompasses multiple values", Critical Perspectives on Accounting, Vol. 9 No. 3, pp. 267-297.

Brown, J. (2009), "Democracy, sustainability and dialogic accounting technologies: taking pluralism seriously", Critical Perspectives on Accounting, Vol. 20 No. 3, pp. 313-342.

Brown, J. (2017), "Democraticizing accounting: Reflections on the politics of "old" and "new" pluralisms", Critical Perspectives on Accounting, Vol. 43 March, pp. 20-46.

Brown, J. and Dillard, J. (2013), "Critical accounting and communicative action: On the limits of consensual deliberation", Critical Perspectives on Accounting, Vol. 24 No. 3, pp. 176-190.

Brown, J. and Dillard, J. (2015a), "Dialogic accountings for stakeholders: On opening up and closing down participatory governance", Journal of Management Studies, Vol. 52 No. 7, pp. 961-985.

Brown, J. and Dillard, J. (2015b), "Opening accounting to critical scrutiny; Towards dialogic accounting for policy analysis and democracy", Journal of Comparative Policy Analysis: Research and Practice, DOI: 10.1080/13876988.2014.989684

Brown, J., Dillard, J., \& Hopper, T. (2015), “Accounting, accountants and accountability regimes in pluralistic societies: Taking multiple perspectives seriously", Accounting, Auditing \& Accountability Journal, Vol. 28 No. 5, pp. 626-650.

Brown, J. and Tregidga, H. (2017), "Re-politicizing social and environmental accounting through Rancière: On the value of dissensus", Accounting, Organizations and Society, Vol 61 (August), pp. 1-21.

Catchpowle, L. and Smyth, S. (2016), "Accounting and social movements: An exploration of critical accounting praxis", Accounting Forum, Vol 40 No. 3, pp. 220-234.

Cooper, C. and Johnston, J. (2012), "Vulgate accountability: Insights from the field of football", Accounting, Auditing \& Accountability Journal, Vol. 25 No. 4, pp. 602-634.

Cooper, C., Taylor, P., Smith, N. and Catchpowle, L. (2005), "A discussion of the political potential of social accounting", Critical Perspectives on Accounting, Vol. 16 No. 7, pp. 951-974.

Cooper, S., and Owen, D. (2007), "Corporate social reporting and stakeholder accountability: The missing link", Accounting, Organizations and Society, Vol. 32 No 7-8, pp. 649-667.

Crown Minerals Act 1991, available at: http://www.legislation.govt.nz/act/public/1991/0070/latest/DLM242536.html～(accessed 25 February 2019).

Dahl, R. A. (1957), "The concept of power", Behavioral Science, pp. 201-215.

Davison, I. (2013), "Deep seas law 'a sledgehammer'”, The New Zealand Herald, 9 April, available at: http://www.nzherald.co.nz/nz/news/article.cfm?c_id=1\&objectid=10876284 (accessed 25 February 2019).

Day, P. and Klein, D. (1987), Accountabilities: Five public services, Tavistock, London, England. 
Deegan, C. (2017), "Twenty five years of social and environmental accounting research within Critical Perspectives on Accounting: Hits, misses and ways forward", Critical Perspectives on Accounting, Vol. 43 March, pp. 65-87.

Deranty, J.P. (2003), "Jacques Rancière's contribution to the ethics of recognition", Political Theory, Vol. 31 No. 1, pp. 136-156.

Dierkes, M. and Preston, L. (1977), “Corporate reporting for the physical environment: A critical review and implementation proposal", Accounting, Organizations and Society, Vol. 2 No. 1, pp. 3-22.

Dillard, J. and Brown, J. (2012), "Agonistic pluralism and imagining CSEAR into the future", Social and Environmental Accountability Journal, Vol. 32 No. 1, pp. 3-16.

Dubnick, M. and Justice, J. (2004), "Accounting for accountability", paper presented at the Annual Meeting of American Political Science Association, 2 September-5 September, Chicago, IL, available at: http://pubpages.unh.edu/dubnick/papers.html (accessed 10 January 2016).

Estes, N. (2019), Our history is the future. New York, NY: Verso.

Exclusive Economic Zone and Continental Shelf (Environmental Effects) Act 2012, available at: http://legislation.govt.nz/act/public/2012/0072/79.0/DLM3955428.html (accessed 25 February 2019).

Factiva. (n.d.), "Factiva: Global news database \& licensed content", available at: https://www.dowjones.com/products/factiva/

Frykberg, E. (2017), "Anadarko abandons NZ oil search", Radio NZ, 28 November, available at: https://www.radionz.co.nz/news/business/344894/anadarko-abandons-nz-oil-search (accessed 18 December 2017).

Gallhofer, S., Haslam, J., and Yonekura, A. (2015), "Accounting as differentiated universal for emancipatory praxis", Accounting, Auditing \& Accountability Journal, Vol. 28 No. 5, pp. 846-874.

Gardner, C. (2013), "Drilling about to start if Anadarko sticks to plans", Waikato Times, 21 November, available at: http://www.stuff.co.nz/waikato-times/news/9423826/Drilling-about-to-start-ifAnadarko-sticks-to-plans (accessed 18 December 2017).

Gray, A. and Jenkins, B. (1993), "Codes of Accountability in the New Public Sector", Accounting, Auditing \& Accountability Journal, Vol. 6 No. 3, pp. 52-67.

Gray, R., Owen, D. and Maunders, K. (1991), "Accountability, corporate social reporting, and the external social audits", Advances in Public Interest Accounting, Vol. 4, pp. 1-21.

Greenpeace of New Zealand Inc. v The Environmental Protection Authority. (2013), NZHC 3482, available at: http://www.epa.govt.nz/Publications/judicial_review.pdf (accessed 18 December 2017).

Greens. (2017), "Climate Protection Plan", available at: https://www.greens.org.nz/climate-protection-plan (accessed 18 December 2017).

Greens. (2019), "Murdoch report another nail in the coffin for Anadarko Amendment", available at: https://www.greens.org.nz/news/press-release/murdoch-report-another-nail-coffin-anadarkoamendment (accessed 26 September 2019).

Greiling, D., and Spraul, K. (2010), "Accountability and the challenges of information disclosure", Public Administration Quarterly, Vol. 34 No. 3, pp. 338-377.

Guthrie, J. and Parker, L. (2017), "Reflections and projections: 30 years of the interdisciplinary accounting, auditing and accountability search for a fairer society", Accounting, Auditing \& Accountability Journal, Vol. 30 No. 1, pp. 2-17.

Horton, J., Macve, R. and Struyven, G. (2004), "Qualitative research: experience in using semi-structured interviews", in Humphrey, C. and Lee, B. (Eds.), The Real Life Guide to Accounting Research: a BehindThe-Scenes View of Using Qualitative Research Methods. Elsevier Science, Amsterdam, The Netherlands, pp. 339-358.

Jacobs, K. (2000), “Evaluating accountability: Finding a place for the Treaty of Waitangi in the New Zealand public sector", Accounting, Auditing \& Accountability Journal, Vol. 13 No. 3, pp. 360-380.

Kaler, J. (2002), "Morality and Strategy in Stakeholder Identification", Journal of Business Ethics, Vol. 39 No 1, pp. 91-100.

Keil, K. (2015), "Spreading oil, spreading conflict? Institutions regulating Arctic oil and gas activities", The International Spectator, Vol. 50 No. 1, pp. 85-110. 
Key, J. (2010), "Raw data: John Key's speech. Statement to Parliament", available at: http://www.nbr.co.nz/article/raw-data-john-keys-speech-118260 (accessed 12 January 2016).

King, N. and Brooks, J. (2017), Template analysis for business and management students. SAGE Publications, London, England.

Klein, N. (2014), This changes everything: Capitalism vs. the climate, Simon \& Schuster, New York, NY.

Laclau, E. (2000), "Identity and hegemony: the role of universality in the constitution of political logics", in Butler, J., Laclau, E. and Zizek, S. (Eds), Contingency, Hegemony and Universality, Verso, London, England, pp. 44-89.

Laine, M. and Vinnari, E. (2017), "The transformative potential of counter accounts: a case study of animal rights activism", Accounting, Auditing \& Accountability Journal, Vol. 30 No. 7, pp. 1481-1510.

Lee, B. and Saunders, M. (2017), Doing case study research: for business and management students, SAGE Publications, London, England.

Li, Y. and Mckernan, J. (2016), "Human rights, accounting, and the dialectic of equality and inequality", Accounting, Auditing \& Accountability Journal, Vol. 29 No. 4, pp. 568-593.

Llewelyn, S. and Northcott, D. (2007), "The "singular view" in management case studies", Qualitative Research in Organizations and Management: An International Journal, Vol. 2 No. 3, pp. 194-207.

Loughrey, D. (2016), "Council green as grass on oil exploration issue”, Otago Daily Times, 16 November, available at: https://www.odt.co.nz/news/dunedin/dcc/council-green-grass-oil-exploration-issue (accessed 17 November 2016).

Manning, B. (2014), "Anti-drilling hikoi arrives in Auckland", The New Zealand Herald, 30 September, available at: http://www.nzherald.co.nz/nz/news/article.cfm?c_id=1\&objectid=11334028 (accessed 1 May 2015).

Manning, B. and Blockhouse, M. (2013), "Anadarko drilling protest heads to court", The New Zealand Herald, $26 \quad$ November, available at: http://www.nzherald.co.nz/nz/news/article.cfm?c_id=1\&objectid=11163074 (accessed 1 May 2015).

Mathews, M. (1997), "Twenty-five years of social and environmental accounting research: Is there a silver jubilee to celebrate?" Accounting, Auditing \& Accountability Journal, Vol. 10 No. 4, pp. 481-531.

Ministry for Culture and Heritage. (n.d.), "New Zealand History", available at: http://www.nzhistory.net.nz (accessed 1 May 2015).

Ministry for Culture and Heritage. (2014), "The Treaty debated", available at: https://nzhistory.govt.nz/politics/treaty/the-treaty-in-practice/the-treaty-debated (accessed 26 September 2019).

Mouffe C. (2000), "Deliberative democracy or agonistic pluralism", Institute for Advanced Studies (IHS), Vienna, Political Science Series, Vol. 72.

Mouffe, C. (2005), On the political, Routledge, Abingdon, England.

Mouffe, C. (2013), Agonistics: Thinking the world politically, Verso, London, England.

Murdoch, S. (2019), "External review into how the non-interference provisions of the Crown Minerals Act are effected", available at: http://img.scoop.co.nz/media/pdfs/1908/externalreviewnoninterferenceprovisionscrownmineralsa ct.pdf (accessed 26 September 2019).

Myers, M. and Newman, M. (2007), "The qualitative interview in IS research: Examining the craft", Information and Organization, Vol. 17, pp. 2-26.

New Zealand Parliamentary Library. (2013), “Crown Minerals (Permitting and Crown Land) Amendment Bill 2012 (Supplementary Order Paper No 205)", available at: https://www.parliament.nz/en/pb/billsand-laws/bills-digests/document/50PLLaw20311/crown-minerals-permitting-and-crown-land-bill2012-supplementary (accessed 21 November 2016).

New Zealand Petroleum and Minerals. (2017), "Block Offer 2017", available at: https://www.nzpam.govt.nz/permits/petroleum/block-offer/2017/ (accessed 25 Aug 2017).

Newell, P. and Wheeler, J. (2006), "Rights, resources and the politics of accountability: An introduction", in Newell, P. and Wheeler, J. (Eds.), Rights, resources and the politics of accountability, Zed Books, London, England, pp. 1-36.

Norval, A. (2009), "Democracy, pluralization, and voice”, Ethics \& Global Politics, Vol. 2 No. 4, pp. 297-320.

Norval, A. (2012), "Writing a name in the sky": Ranciere, Cavell, and the possibility of egalitarian inscription, American Political Science Review, Vol. 106 No. 4, pp. 810-826. 
O'Dwyer, B., Unerman, J. and Bradley, J. (2005), "Perceptions on the emergence and future development of corporate social disclosure in Ireland", Accounting, Auditing \& Accountability Journal, Vol. 18 No. 1, pp. 14-43.

O'Regan, T. (1991), "Old myths and new politics: Some contemporary uses of traditional history", available at: http://www.nzjh.auckland.ac.nz/docs/1992/NZJH_26_1_03.pdf (accessed 18 December 2017).

O'Sullivan, D. (2017), "Why the Indigenous in New Zealand have fared better than those in Canada", available at: https://theconversation.com/why-the-indigenous-in-new-zealand-have-fared-betterthan-those-in-canada-84980 (accessed 26 September 2019).

Owen, D. (2008), "Chronicles of wasted time?: A personal reflection on the current state of, and future prospects for, social and environmental accounting research", Accounting, Auditing \& Accountability Journal, Vol. 21 No. 2, pp. 240-267.

Parker, L. (2005), "Social and environmental accountability research: A view from the commentary box", Accounting, Auditing \& Accountability Journal, Vol. 18 No. 6, pp. 842-860.

Phillips, N. and Hardy, C. (2002), Discourse analysis: Investigating processes of social construction, SAGE Publications, Thousand Oaks, CA.

Pirsoul, N. (2017), "Identity between police and politics Ranciere's political theory and the dilemma of Indigenous politics", Critical Horizons: A Journal of Philosophy and Social Theory, Vol. 18 No. 3, pp. 248-261.

Poulton, L. (Producer). (2015), "Brazil's troubled waters [Interactive]", The Guardian, 25 June, available at: http://www.theguardian.com/environment/ng-interactive/2015/jun/25/brazils-gamble-on-deepwater-oil-guanabara-bay (accessed 12 January 2016).

Prno, J. and Slocombe, D. S. (2012), "Exploring the origins of 'social license to operate' in the mining sector: Perspectives from governance and sustainability theories", Resources policy, Vol. 37 No. 3, pp. 346357.

Radio NZ. (2018), "Oil, gas exploration a 'kick in the guts' for Taranaki-mayor", Radio NZ, 12 April, available at: http://www.radionz.co.nz/news/national/354816/oil-gas-exploration-move-a-kick-in-the-gutsfor-taranaki-mayor (accessed 25 February 2019).

Rancière, J. (1992), "Politics, identification, and subjectivization", The Identity in Question, Vol. 61, pp. 58-64.

Rancière, J. (1999), Disagreement: Politics and Philosophy (Trans. by J. Rose), University of Minnesota Press, Minneapolis, MN.

Rancière, J. (2006), Hatred of democracy (Trans. By S. Concoran), Verso, London, England.

Rancière, J. (2010), Dissensus: On Politics and Aesthetics (Trans. by S. Corcoran). Continuum International Publishing Group, London, England.

Ranson, S. (2003), "Public accountability in the age of neo-liberal governance", Journal of Education Policy, Vol. 18 No. 5 , pp. 459-480.

Roberts, J. (2009), "No one is perfect: The limits of transparency and an ethic for 'intelligent' accountability", Accounting, Organizations and Society, No. 34 Vol. 8, pp. 957-970.

Robson, S. (2012), "Rena: one year on", 3News, 5 October, available at http://www.3news.co.nz/nznews/rena-one-year-on-2012100505 (accessed 11 June 2014).

Roy, E. (2017), "Jacinda Ardern to be New Zealand's next PM after Labour coalition deal", The Guardian, 19 October, available at: https://www.theguardian.com/world/live/2017/oct/19/new-zealandelection-winston-peters-prime-minister-bill-english-jacinda-ardern-live (accessed 18 December 2017).

Ruckstuhl, K. (2013), "Introduction". In The Māori and Mining Research Team (Eds.), Māori and mining, Te Poutama Māori: University of Otago, Otago, New Zealand, pp. 3-7.

Ruckstuhl, K. (2017), "A shift in the playing field": Indigenous sovereignty and the philosophy of Jacques Rancière", AlterNative, Vol. 13 No. 1, pp. 35-42.

Ruckstuhl, K., Gale, K., Carter, L. Ellison, E., Flack, S. and Russell, K. (2017), Kā Rūnaka expectations for oil and gas companies in East Otago. Kāi Tahu ki Otago Ltd: Dunedin, NZ.

Ruckstuhl, K., Thompson-Fawcett, M. and Rae, H. (2014), "Māori and mining: Indigenous perspectives on reconceptualising and contextualising the social licence to operate", Impact Assessment and Project Appraisal, Vol. 32 No. 4, pp. 304-314. 
Shearer, T. (2002), "Ethics and accountability: From the for-itself to the for-the-other", Accounting, Organizations and Society, Vol. 27 No. 6, pp. 541-573.

Sinclair, A. (1995), "The chameleon of accountability: Forms and discourses", Accounting, Organizations and Society, Vol. 20, No. 2, pp. 219-237.

Smallman, E. (2013), "Protesters' flotilla awaits drillship", Waikato Times, 18 November, available at: http://www.stuff.co.nz/national/9410561/Protesters-flotilla-awaits-drillship $\quad$ (accessed 18 December 2017).

Smyth, S. (2012), "Contesting public accountability: A dialogical exploration of accountability and social housing", Critical Perspecives on Accounting, Vol. 23 No. 3, pp. 230-243.

Smyth, S. (2017), "Public Accountability: Reforms and resistance in social housing", Public Management Review, Vol. 19 No. 2, pp. 212-231.

Stake, R. E. (1995), The art of case study research, SAGE Publications, Thousand Oaks, CA.

Stewart, J. (1984), "The role of information in public accountability", in Hopwood, T. and Tomkins, C. (Eds.), Issues in public sector accounting, Phillip Allan, Deddington, England, pp. 13-34.

Taranaki Daily News. (2013), "Tiny Greenpeace boat takes on drillship giant", Taranaki Daily News, 20 November, available at: http://www.stuff.co.nz/taranaki-daily-news/news/9419753/TinyGreenpeace-boat-takes-on-drillship-giant (accessed 9 October 2019).

University of Canterbury. (n.d.), "Consultation with Māori", available at: https://www.canterbury.ac.nz/research/maori-consultation/ (accessed 25 February 2019).

Walker, R. (1990), Ka whawhai tonu matou: Struggle without end, Penguin Books, Auckland, New Zealand.

Walton, S. (2007), "Site the mine in our backyard! Discursive strategies of community stakeholders in an environmental conflict in New Zealand", Organization \& Environment, Vol. 20 No. 2, pp. 177-203.

Windsor, C. and McNicholas, P. (2012), "The BP gulf oil spill: Public and corporate governance failures", paper presented at the $11^{\text {th }}$ A-CSEAR Conference, 2-4 December, Wollongong, Australia. Available at: http://ro.uow.edu.au/acsear2012/2012/papers/37/ (accessed 11 June 2014).

Wretched of the Earth. (2019), "An open letter to Extinction Rebellion", available at: https://www.redpepper.org.uk/an-open-letter-to-extinction-rebellion/ (accessed 26 September 2019). 